\title{
Royong Ana': A Form Of Parenting Pattern In Makassarese Family South Sulawesi
}

\author{
Arifin Manggau ${ }^{1}$, Arifuddin Usman ${ }^{2}$, Ahmad Syawaluddin $^{3}$ \\ \{arifin.manggau@unm.ac.id ${ }^{1}$, arifus1303@gmail.com ${ }^{2}$, unmsyawal@unm.ac.id ${ }^{3}$ \} \\ ${ }^{1,3}$ Universitas Negeri Makassar, Faculty of Education, Indonesia \\ ${ }^{2}$ Universitas Negeri Makassar, Faculty of Sport Science, Indonesia
}

\begin{abstract}
Royong Ana' is a form of affection given by parents to the children. Among other things as a mother must have the intelligence in raising, caring, loving, and always being patient to her children. Being hummed without the accompaniment of musical instruments, the baby is rocked slowly until he sleeps. According to Arifin Manggau (2016: 78), that lullaby songs for a child are a mother's prayer to ensure that one day the child can live happily, be dignified in the community, be a useful person and be able to serve his parents, making it easier for his sustenance.[1] The problem in this study is what parenting pattern contained in Royong Ana' of the Makassarese tribe in South Sulawesi. The purpose of this study was to study and analyze Royong Ana' as a parenting pattern for Makassarese tribe community in South Sulawesi. This research method is qualitative with descriptive analysis approach. The focus of the study and data collected are related to the research problem. The techniques of data collection are observation, interview and document study. The validity of the data uses the triangulation method. Data analysis procedures are data reduction, data presentation and conclusion. The results of this study indicate the following matters; forming good characters and good ethics. Morality means the role of morals and good behaviour in life (character) that needs to be based on or understood by a clear and a good mind (benevolence) such as faith, piety, honesty, example, caring, openness, togetherness, and good manners.
\end{abstract}

Keywords: Royong Ana', Form of Parenting, Makassarese Tribe.

\section{Introduction}

Royong Ana' is a children's lullaby for Makassarese people in South Sulawesi. This song is inherited to the successor generation in the community, sung in a habit that is often done by mothers when putting their babies to sleep. In addition, this song contains a moral message and parents' expectations for the child's future. Due to the poetic words and meanings, often do adults have goosebumps when listening to this song.

The origin of Royong can be traced through ancient history that was originated from the myth of the king genealogy who ruled in South Sulawesi. According to Prof. Dr. H.A Kadir Manyambeang, in Solihing (2004), after the Galigo period, during seven periods (Pitupariameng) the motherland (Aleq Lino) experienced a government vacuum that resulted in community clashes called chaos (Sianre Bale) and was very difficult to overcome by clan leaders.[2] Due to this event, a person who came down from the sky (Tomanurung) appeared. Almost every region in South Sulawesi has a story about Tomanurung, including Gowa. 
Tomanurung in Gowa named Putri Tamalate, a woman who came down from the sky with two court ladies equipped with Gaukang.

These court ladies sing Royong along with the arrival of Putri Tamalate to the motherland. The Royong song was heard by dwellers of Gallarang Mangasa, who then reported it to the leaders of the clans (Batesalapang and Paccallayya). Batesalapang and Paccallayya went to see Tomanurung. Tomanurung married the first king in Gowa (Karaeng Bayo). In this marriage, Royong was sung again by the two court ladies of Putri Tamalate. When the daughter of Karaeng Bayo and Putri Tamalate, named Karaeng Tumasalangga Baraya was born, Royong was sung again by the ladies.

After that the ladies disappeared. Based on this, it was concluded that Royong came from heaven and came down to earth along with the arrival of Tomanurung in Gowa. This tradition is then carried out in every traditional ceremony or rite of Makassarese people, especially in the cycle of human life including children's lullaby song or Royong Ana'. The song is also a tradition for Makassarese community when they want to put their children to sleep, which is certainly rich in values and cultural significance for the community.

Royong Ana' is an expression of parental affection to their children. Not only should a mother have the intelligence in terms of caring, loving, and always being patient with their children. She has to be able to hum Royong Ana' without the accompaniment of musical instruments while the baby is rocked slowly until he sleeps. The expectations of parents for their children expressed are as a lullaby song, a fortune, a danger repellent, a form of parenting, a mother's prayer, a hope and dream, and a shape of morals for children. There is a good message and doctrine in the song so that it can cause people to be better in living their daily lives. [3] Royong $A n a^{\prime}$ is only sung to put the baby to sleep, and it cannot be sung in other circumstances such as war or harvest parties and other parties because this song is intended for lullaby prayers.

Fathur Rasyid in his book "educate your children with music" said that singing has many benefits, including: 1) Listening and enjoying singing, 2) Experiencing pleasure when singing together, 3) Expressing thoughts, feelings and moods, 4 ) Learning to control the sound, 5) Exploring inner feelings, 6) Performance ability, 7) Creativity ability, 8) Introducing humanitarian understanding, 9) Taste sensitivity, 10) Focused concentration, 11) Embed creativity, 12) Adding vocabulary, 13) Being healthy, 14) Being able to control development. [4]

Royong Ana' in the community is one form of popular folk songs as explained by Jan Harold Brunvand (James Danandjaja: 1984; 141) that "people's singing is one genre or form of folklore consisting of words and songs, which circulates orally among certain collective members, are traditional in forms, and have many variants". [5]

A child's lullaby song is a mother's prayer for her child to live happily, to be dignified in the community, to become someone useful and be able to serve their parents, to be blessed with sustenance.[1] Thus basically, the Royong Ana' song in Makassar society is regarded as parenting media for children such as the forming of good character and ethics.

Therefore, based on the background above, the focus of the research is: "How is Royong $A n a$ ' as a parenting pattern in the family of Makassarese society in South Sulawesi. "?

\section{Research Method}

This research is a qualitative approach using descriptive qualitative analysis. The focus of this research is the study of Royong $A n a^{\prime}$ as a form of parenting in the family of Makassarese society in South Sulawesi. The research is a descriptive study on the phenomena 
of Royong Ana' as a form of parenting in the family. The focus of this research is also oriented to scientific journals which are certainly from the data found in the research location. From the total number of communities supporting Royong Ana' in Gowa, South Sulawesi, Bontonompo sub-district was selected as the object of this study.

Interviews were conducted with teachers to obtain data about Royong ana' as a form of parenting in the family using interview guidelines. This observation technique is used to observe the description of Royong Ana' as a form of parenting in the family of Makassarese community in South Sulawesi. Document review is conducted to obtain data in the form of information or written reports needed in the research. The document is in the form of photographs and the like. After collecting the data in the research location, the next step taken by the researcher is to analyze using analysis techniques as follows; a. analyze any information obtained through observation and interviews, b. find meaning through achievement and elaboration index, c. categorize and classify data by comparing raw data collected by systematically transforming so that the type of relationship does not lose its context. Data validation used is the triangulation technique through the following steps; a. Data reduction as an activity that includes selecting data, focusing, simplifying and abstracting the data examined in the field, $b$. Data presentation as an activity of compiling data or information that is good and right so that it can be made conclusions and further action, $\mathrm{c}$. Draw conclusions as the stages of interpretation and conclusions of all the final results of research that have been given.

\section{Results and Discussion}

The results of this study indicate the following matters; forming good character and ethics. Morality the role of morals and good behavior in living the life (character) which is certainly based or born by a clear and good mind (benevolence), such as faith, piety, honesty, example, caring, openness, togetherness, and manners. From the results of our interviews with informants, people used to believe that when putting children to sleep there are some things we cannot do, which are as follows:

a. Do not put the child to sleep at the time between asr and early evening.

b. Before putting a 40-day-old baby to sleep on the swing, they previously place a kitten on the swing as their belief to take the spirit of the cat which is commonly referred by Makassarese people as Nialle Sumangakna.

c. Do not put children to sleep singing Royong when a neighbor has just died.

d. Do not put the child to sleep outside the house or in front of the door when Royong is hummed.

Royong Pattinro Ana' does not have a specific requirement among Makassarese community in general. For the type of sarong used, there is no special meaning where various types of sarong can be used, as long as the sarong is strong and not easily torn. The time to sing Royong Pattinro Ana' is not bound except the time between Asr and early evening. They forbade to put a baby to sleep between this time because they believed that it was Pammali. Pammali is a habit prohibited in the Buginese-Makassarese customs. When a child is getting sleepy and wants to sleep, we can help them except at the time mentioned above. It is a good idea to put the child to sleep in the house because Makassarese people believe that outside of the house there are many bad things hanging around, in this case it is referred to as something that is not good like the supernatural things that can disturb small children. In this case, people are afraid that the small child gets sick because of being struck by spirits or alike. 
To sing Royong Pattinro Ana', there is no bound poetry needed, people can sing Royong Pattinro Ana' with any poem as long as the words contain positive things. Makassarese people believe that what is being sung in Royong Pattinro Ana' can become reality someday. The poem contains the hopes and prayers that are sung by Paroyong. In singing it, old women are usually crying because they appreciate the poetry that they chant.

\section{Values Contained in Royong Pattinro Ana'}

In general, there are 4 types of Royong functions, namely as a lullaby; as an inviter of fortune and repellent for reinforcements or disasters; as an endorsement of customs or customs procedure of the Makassar community group; as a medium for character education or understanding of positive norms for future generations. From the four Functions of Royong above, it can be explained that the values contained in Royong Pattinro Ana' are very numerous. The one mentioned above is as a medium for character education or understanding of positive norms for the next generation. Young children sung with Royong ana' are expected to know and understand the positive norms that exist and not to do things that deviate from what is expected. Royong Pattinro Ana' also contains poems filled with hope and prayers from parents to their children to be able to grow and develop properly. Parents also sometimes sing Royong poems with sadness that contains sad words about various things that happen in life. Royong Pattinro Ana' also functions as a means to provide enthusiasm in living life, be patient and sincere, never give up and always give thanks to God Almighty. In Royong poetry, there is usually a connotation with the intention to offend something negative. Something negative is used as a learning to take lessons from bad things happened in life of a person.

Examples of Royong poems that have meaningful connotations are as follows;

Lontara

Latin:

$$
\begin{gathered}
\text { Ka'deja kuissseng memang } \\
\text { Bulo natangke pariya } \\
\text { Manna malebong } \\
\text { Jamarrok tama'lalangku }
\end{gathered}
$$

Translation:

If I knew long ago

Pariah-stemmed bamboo

Even though it's beautiful

I would not want to

The purpose of the poem above is someone who feels sorry to know someone just because of his/her looks, the outside is good, but it turns out that his/her character is not as beautiful as he seems. This message emphasizes the nature of one's dishonesty over what appears on his face, but his heart does not say so. This is the form of parenting for 
Makassarese people, with various figurative words used in singing as a provision for the children to be mature from an early age. Beside that, the singing is also used to satirize the child who disregard all parents' commands. According to Baumrind, quoted by Muallifah, parenting in principle is parental control: "Namely how parents control, guide, and accompany their children to carry out their developmental tasks towards the process of maturity." [6]

Meanwhile, Hetherington and Porke (1999) cited by Sanjiwani proposed that parenting is a way for parents to interact with children in total, which includes the process of caring, protecting and teaching children. [7]

According to Hersey and Blanchard (1978) quoted by Garliah, parenting is a form of leadership.[8] Understanding leadership itself is how to influence someone, in this case parents play a strong influence on their children. But Karen quoted by Muallifah emphasize more on how the quality of good parenting, that is, parents who are able to monitor all children's activities, even if the child's condition is in good or bad condition, parents must provide support.[6]

Providing good and positive parenting to children will foster children's positive selfconcepts in assessing themselves. This may start from the community that does not limit the association of children but still guide them, so that children can be objective, and respect themselves, by trying to get along with more friends. From some of the definitions above, it can be concluded that parenting is how parents interact with children by giving attention to children and giving direction so that children are able to achieve what they want.

\section{Role of Family in Childcare}

The role of the family is so important for the growth and development of the child's personality, in social, cultural and religious development. Some of the family role in childcare are as follows:

a) Maintaining a harmonious relationship in the family through the adoption of Islamic parenting from an early age, which starts from before marriage, both men and women should choose a partner in accordance with religious guidance, because a good partner is likely to provide good care. Furthermore, when caring for a child from the womb, after birth and adulthood, parents provide full guidance of compassion with religious guidance and religious education, for example, from the smallest thing, how to be polite to older people.

b) Guiding children with patience and sincerity will deliver the child's success. Whenever parents describe parenting patiently, indirectly parents nurture into the child about patience. When a person is embedded in patience, he will be able to control himself, to do good things for his life and can establish good relationships with other individuals.

c) Happiness of children is a duty of parents where parents must accept the child as he/she is, give thanks for the blessings that have been given by Allah SWT, and able to develop the potential of the child with guidance.

\section{Factors that Influence Parenting}

In addition to the role of family in childcare, there are factors that influence parenting. According to Mussen quoted by Marcelina, there are several factors that influence parenting, namely the neighborhood. Families who live in big cities and families who live in rural areas are different in their parenting style. Families who live in big cities have great worries when 
their children leave the house, whereas families who live in villages do not have big concerns with children who leave the house.

Subculture culture is also included in the factors that influence parenting. In each culture the parenting is applied differently, for example in one culture children are allowed to argue about the rules set by parents, but this does not apply to all cultures. Families who have different social status also apply different parenting patterns. Thus, the role of mutual cooperation for parents in the Makassarese community is one form of parenting that is forming children in the early age have good character and personality.

\section{Conclusion}

Based on the problem above, it can be concluded that the form of parenting contained in Royong Ana' in Makassarese community in South Sulawesi, namely; forming good character and ethics. Morality has a meaning as a role of morals and good behavior in living life (character) which is certainly based or born by a clear and good mind (benevolence) such as faith, piety, honesty, example, caring, openness, togetherness, and manners. All of these are expressed in Royong Ana' with various figurative words as a polite method of parents to foster maturity in their children.

\section{References}

[1] 'View of Iyabelale as an Accompaniment to Magical Sleeping for Children in the Bugis Ethnic Groups of South Sulawesi'. [Online]. Available: https://journal.unnes.ac.id/sju/index.php/jed/article/view/24243/11163. [Accessed: 10Oct-2019].

[2] Solihing, Royong: Musik Vokal Komunikasi Gaib Etnik Makassar. Makassar: Makassar: Masagena Press, 2004.

[3] Firduansyah, Dedy., Tjetjep Rohendi Rohidi, Udi and Utomo., 'Guritan: Makna Syair Dan Proses Perubahan Fungsi Pada Masyrakat Melayu Di Besemah Kota Pagaralam., . Semarang: Pendidikan Seni Pascasarjana UNNES', Cathar. J. Arts Educ., pp. 5(1), $71-$ 78.

[4] Rasyid, F. (2010). Cerdaskan Anakmu dengan Musik. Yogyakarta: Diva Press. .

[5] Danandjaja, James. 1984. Folklor Indonesia: Ilmu Gosip, Dongeng, dan Lain-Lain. Jakarta: PT Temprint. .

[6] Muallifah, Psycho Islamic Smart Parenting, DIVA Press (Anggota IKAPI). (2009). DIVA Press.

[7] N. L. P. Y. Sanjiwani and I. G. A. P. W. Budisetyani, 'Pola Asuh Permisif Ibu dan Perilaku Merokok Pada Remaja Laki-Laki di Sma Negeri 1 Semarapura', J. Psikol. Udayana, vol. 1, no. 2, Apr. 2014.

[8] Lili Garliah, 'Lili Garliah.:Peran Pola Asuh Orang Tua dalam Memotivasi Berprestasi. Jurnal psikologi,Vol. 1, No. 1, Juni 2005. (2005’. 
